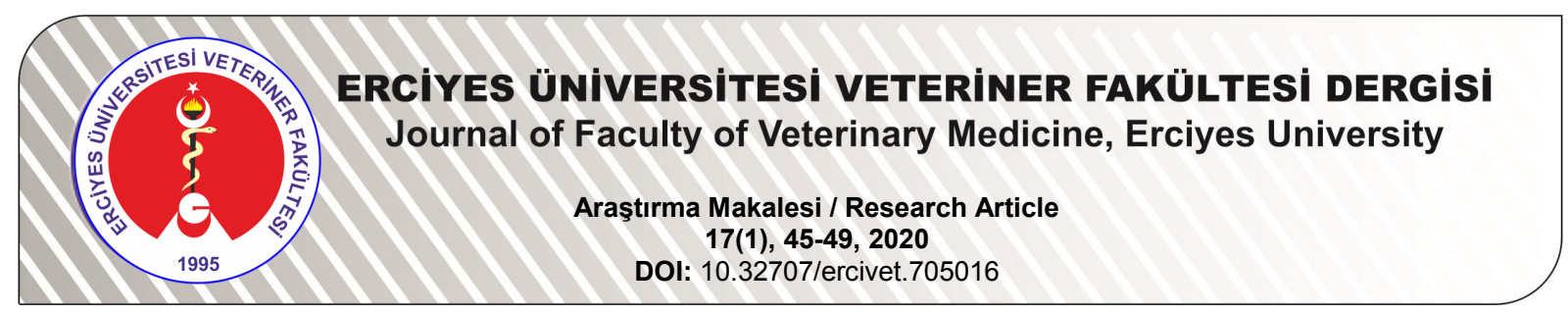

The Effect of Milkman on Productivity and Revenue in Dairy Herds*

\author{
Aytaç AKÇAY ${ }^{1}$, Savaş SARIÖZKAN², Mehmet KÜÇÜKOFLAZ ${ }^{3}$, Güven GÜNGÖR ${ }^{3}$
}

\author{
${ }^{1}$ Erciyes University, Faculty of Veterinary Medicine, Department of Biometrics, Kayseri-TURKEY \\ ${ }^{2}$ Erciyes University, Faculty of Veterinary Medicine, Department of Animal Health Economics and Management, Kayseri- \\ TURKEY \\ ${ }^{3}$ Erciyes University, Graduate School of Health Sciences, Department of Zootechnics, Kayseri-TURKEY
}

Correspondence Author: Savaş SARIÖZKAN, E-mail: ssariozkan@erciyes.edu.tr; ORCID: 0000-0003-2491-5152 How to cite: Akçay A, Sarıözkan S, Küçükoflaz M, Güngör G. The effect of milkman on productivity and revenue in dairy herds. Erciyes Üniv Vet Fak Derg 2020;17(1): 45-49.

Summary: Nowadays, milking process in a dairy farm is carried out with the "animal, human and machine" trio closely related to each other. Expected success in milking process is ensured by the animal's accustomedness to the milking machine, the skill and experience of the milkman, and the functional conformity of the milking machine. The aim of this study was to determine the effect of milkman on milk productivity and revenue. As study material, average milk yields obtained from 387 milking of 35 Holstein cows raised in the farm was used. The cows were milked by 6 different milkmen. Linear Mixed Models were used to determine the effect of different milkman and milkman experience on the average milk yields. In addition, the difference in milk yields due to milkman was analyzed in terms of economy. In the study, it was determined that the individual milkman and milkman experience were significant for the average milk yields. Thus, a difference of $2.3 \mathrm{~kg}$ was determined between $1^{\text {st }}$ milkman (the highest average milk yield; $22.6 \pm 0.46 \mathrm{~kg}$ ), and $5^{\text {th }}$ milkman (the lowest average milk yield; $\left.20.3 \pm 0.76 \mathrm{~kg}\right)$, and the difference was statistically significant $(P=0.011)$. This difference in the average milk yield was reflected in 80 liters of additional milk yield per day and $184 €$ (31.9 \$) additional revenue increase achieved in the farm where 35 cows were milked. This difference in income corresponds to the cost of an insured worker. Milkman experience has been split in three categories, the difference between the average milk yield obtained by the least experienced milkman and the average milk yield of the most experienced milkman was found to be statistically significant $(P=0.04)$. This case shows that the experienced milkman income about $156 €$ (27.03 \$) more per day. In conclusion, it was determined that the milkman factor was important for the profitability of the farm in dairy cow. The experienced milkman may earn his own salary with the income increase provided for the farm, and, therefore, economically does not cost extra.

Key words: Cow, income, linear mixed models, milkman, productivity

\title{
Süt Sığırcılığı İşletmelerinde Sağımcının Verimlilik ve İşletme Gelirine Etkisi
}

Özet: Günümüzde süt sığırcılığında sağım süreci birbiriyle yakından ilişkili olan "hayvan, insan ve makine" üçlüsü ile gerçekleştirilmektedir. Sağım sürecinde beklenen başarı, hayvanın sağım makinesine alışkanlığı, sağımcının deneyimi ve sağım makinesinin fonksiyonel uygunluğu ile sağlanır. Bu çalışmanın amacı sağımcının süt verimi üzerine ve işletme gelirine katkısını belirlemektir. Çalışma materyali olarak, 35 adet sağmal Holstein inek bulunan işletmeye ait 387 sağımdan elde edilen süt verimi ortalamaları kullanılmıştır. Inekler 6 farklı sağımcı tarafından sağılmıştır. Araştırmada farklı sağımcı ve sağımcıların deneyimlerinin ortalama süt verimine üzerine etkisini belirlemek için Linear Mixed Models kullanıldı. Ayrıca sağımcıdan kaynaklanan süt verimindeki fark ekonomik olarak analiz edilmiştir. Çalışma sonucunda, bireysel olarak sağımcının ve sağımcı deneyiminin ortalama süt verimi üzerindeki etkisinin önemli olduğu belirlenmiştir. Buna göre, 1. sağımcı (en yüksek ortalama süt verimi; $22.6 \pm 0.46 \mathrm{~kg}$ ) ve 5 . sağımcı (en düşük ortalama süt verimi; $20.3 \pm 0.76 \mathrm{~kg}$ ) arasında günlük ortalama $2.3 \mathrm{~kg}$ 'lık bir fark belirlenmiş ve bu fark istatistiksel olarak önemli bulunmuştur $(P=0.011)$. Sağımcıdan dolayı ortalama süt verimindeki fark; 35 sağmal ineğin bulunduğu işletmede günde yaklaşık 80 It daha fazla süt verimi ve 184 も (31.9 \$)'lik gelir artışı sağlamıştır. Bu gelir farkı, sigortalı bir işçinin maliyetine karşılık gelmektedir. Sağımcı deneyimi üç kategoriye ayrılmıştır, en az deneyimli sağımcıdan elde edilen ortalama süt verimi ile en deneyimli sağımcıdan elde edilen ortalama süt verimi arasındaki fark istatistiksel olarak anlamlı bulunmuştur $(P=0.04)$. Bu durum, deneyimli sağımcının günde yaklaşık 156 も (27.03 \$) daha fazla gelir getirdiğini göstermektedir. Sonuç olarak, süt sığırcılığı işletmesinin karlıığı için sağımcı faktörünün önemli olduğu belirlenmiştir. Tecrübeli sağımcının, kendi giderlerini karşılayacak kadar gelir artışı sağlayabileceği ve işletmeye ilave maliyet oluşturmayacağı ortaya çıkmıştır.

Anahtar kelimeler: Gelir, inek, lineer mixed model, sağımcı, verimlilik

Introduction

Milk is a valuable animal product, for it contained

Geliş Tarihi/Submission Date : 15.10 .2019

Kabul Tarihi/Accepted Date $\quad: 17.12 .2019$

*This paper was presented in the $3^{\text {rd }}$ National Livestock Economics Congress in 2018. essential amino acids, vitamins and minerals (Koyubenbe and Konca, 2006). About 22 million tons of milk is produced in Turkey and $90.58 \%$ of this amount constitutes the cow milk. Therefore, dairy cows has an important place in Turkish livestock production (Çukur and Saner, 2012; Yavuz et al., 2003; 
TÜİK, 2018).

Livestock is a production sector where the highest profitability is targeted as in all commercial activities. The highest profitability can be achieved with high sales revenue and low production costs. Hence, human, cow, land, capital and other resources should be used rationally for higher profitability (Öz and Bilgen, 2002; Bakır and Kibar, 2019).

High milk yield (productivity) per animal in dairy cattle farms will increase sales revenue and have a positive impact on profitability. Milk yield may vary depending on some factors like gender, age, the number of lactations, nutrition, diseases, and milkman (Alpan and Arpacık, 1998).

As a result of diseases, unfavorable care and feeding conditions (management), and the resulting negative animal behavior adversely affect animal welfare, and accordingly, cause losses in product quantity and quality (Bozkurt et al., 2013; Knight et al., 1998; Hemsworth et al., 1998). This shows that there is a relationship between the caretakers' and milkman's attitudes and behaviors of caretakers and the behavioral responses of animals to humans (de Ondarza, 2019). It has been reported that human fear and related stress in cow may cause a decrease in milk yield (Rushen et al., 1999; Breuer et al., 2000). According to a previous study, it was observed that cows exposed to less stress during milking gave more milk than those under stress (Sreekumar, 2019). As a result of these, it is seen that humananimal interactions have a share on milk yield, which may have an effect (positive or negative) on profitability (Hemsworth et al., 1998; Lensink et al., 2001).

Nowadays, milking process in dairy cattle farms is carried out with the "animal, human and machine" trio yield, and to determine the economic reflections of the milkmen on farm income.

\section{Material and Methods}

Study material calculated from average milk yields obtained from 387 milking result of an average of 35 milking Holstein cows on a dairy farm. The mean age and parity of cows were $4.2 \pm 1.4$ and $2.2 \pm 1.1$ respectively. Milk yield data were obtained from a farm with automatic milking unit (2x5 fishbone) and milking twice a day. Cows were milked by six different milkmen with the same level of education (primary school). The income was calculated from retail price of milk. The experience was divided into 3 categories as beginner ( $<2$ years), intermediate $(2-5$ years) and advanced ( $>5$ years).

Linear Mixed Models were used to determine the effect of different milkman and milkman experience on the average milk yields. Linear mixed models are extensions of simple linear models to allow both fixed and random effects, and are particularly used when there is no independence in the data, such as those arising from a hierarchical structure. In this study;

Linear mixed model:

$Y_{i j k}=\mu+S_{i}+D_{j}+(S \times D)_{i j}+e_{i j k}$

$Y_{\mathrm{ijk}}$ : Dependent variable (the average milk yields)

$\mu$ : Constant

\section{$S_{\mathrm{i}}$ : Random and Repeated effect (Milkman)}

$D_{j}$ : Fixed effect (Experience)

$\left(S \times D_{i j}\right.$ : Milkman and Experience interaction

$\mathrm{e}_{\mathrm{ijk}}$ : Random Error term / Residuals

Table 1. Statistical significance of individual milkman effects on average milk yield

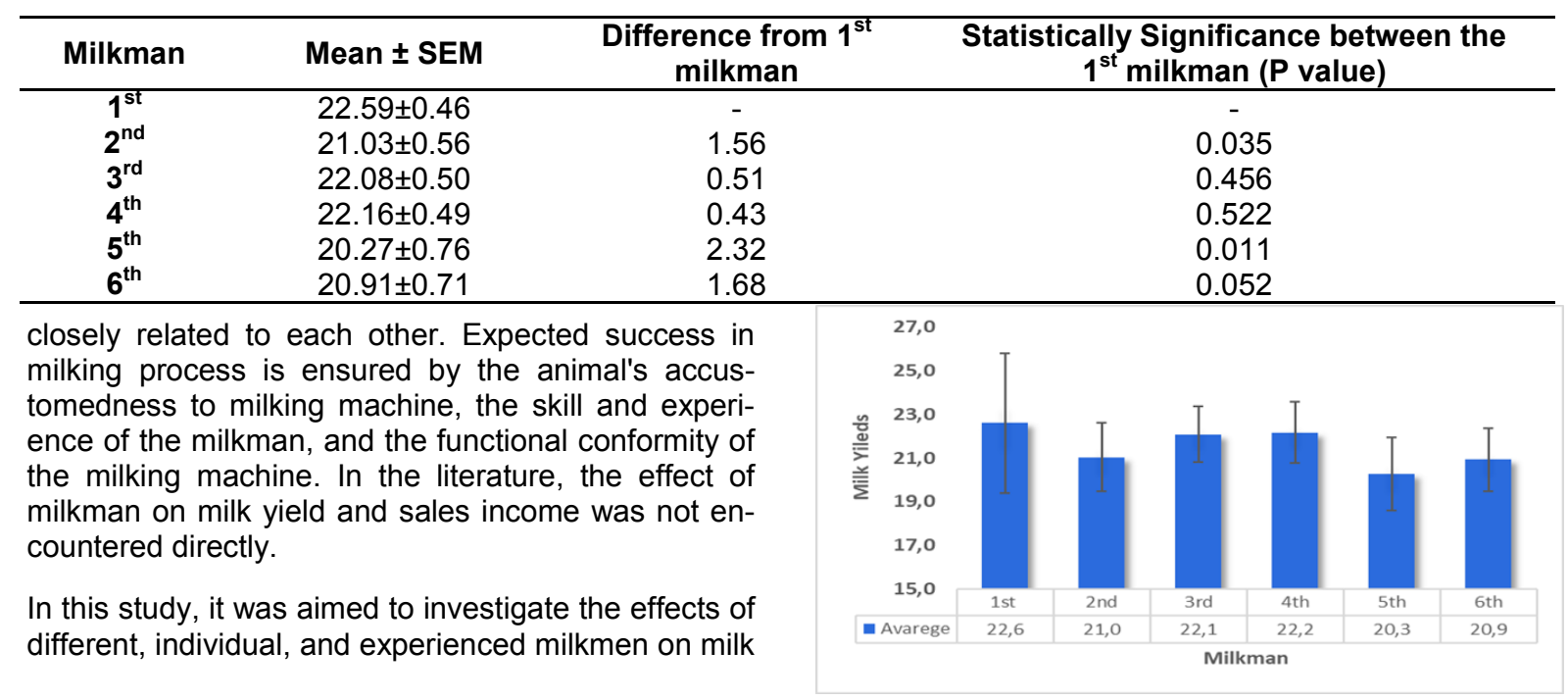

Figure 1. The average milk yields of milkman 
Calculations were given both in TL (も) and USD (\$). Data of milk yield were given as Mean \pm SEM $(\bar{X} \pm S \bar{x})$ in the tables.

\section{Results}

$(2.3$ も-(0.40 \$) X $1.94 \mathrm{~kg})$ and 156 も $(27.03 \$)$ per day for 35 cows. This result shows that the experienced milkman income about 156 も (27.03 \$) more per day in this farm. This price corresponds to the cost of an insured worker (Table 4).

Table 2. Statistical significance of milkman experience on average milk yield

\begin{tabular}{cccc}
\hline $\begin{array}{c}\text { Milkman Experi- } \\
\text { ence }\end{array}$ & Mean \pm SEM & $\begin{array}{c}\text { Difference from } \\
\text { Advanced }\end{array}$ & $\begin{array}{c}\text { Statistically Significance between the } \text { 1 }^{\text {st }} \\
\text { milkman (P value) }\end{array}$ \\
\hline $\begin{array}{c}\text { Advanced } \\
\text { Intermediate }\end{array}$ & $22.59 \pm 0.59$ & - & - \\
Beginner & $21.71 \pm 0.33$ & 1.06 & 0.07 \\
\hline
\end{tabular}

Table 3. The effect of milkman on dairy farm income*

\begin{tabular}{|c|c|c|}
\hline Milkman & Income (も-\$/day) & Total Income (も-\$/farm) \\
\hline $1^{\text {st }}$ & $36.2 も(6.27 \$)$ & 1.267 も $(0.22 \$)$ \\
\hline $2^{\text {nd }}$ & $33.6 も(5.82 \$)$ & $1.176 も(0.20 \$)$ \\
\hline $3^{\text {rd }}$ & $35.4 も(6.13 \$)$ & $1.238 も(0.21 \$)$ \\
\hline $4^{\text {th }}$ & $35.5 も(6.15 \$)$ & $1.243 も(0.22 \$)$ \\
\hline $5^{\text {th }}$ & $32.5 も(5.63 \$)$ & 1.137 も $(0.20 \$)$ \\
\hline $6^{\text {th }}$ & 33.4 も(5.79 \$) & 1.170 も $(0.20 \$)$ \\
\hline
\end{tabular}

* \$ information was obtained from TCMB on November 12, 2019

Table 4. The effect of milkman experience on dairy farm income*

\begin{tabular}{|c|c|c|}
\hline Milkman Experience & Income (も-\$/day) & Total Income (も-\$/farm) \\
\hline Advanced & 36.2 も $(6.27$ \$) & $1.266 も(0.22 \$)$ \\
\hline Intermediate & 34.7 も $(6.01 \$)$ & $1.215 も(0.21 \$)$ \\
\hline Beginner & 33.0 も $(5.72 \$)$ & 1.154 も $(0.20 \$)$ \\
\hline
\end{tabular}

*\$ information was obtained from TCMB on November 12, 2019

In the study, it was determined that the individual milkman efficiency and milkman experience were significant on the average milk yields. According to this, a difference of $2.3 \mathrm{~kg}$ was determined between $1^{\text {st }}$ milkman (the highest average milk yield; $22.6 \pm 0.46 \mathrm{~kg}$ ), and $5^{\text {th }}$ milkman (the lowest average milk yield; $20.3 \pm 0.76 \mathrm{~kg}$ ) and the difference was statistically significant $(P=0.011)$ (Table 1).

Milkman experience has been split in three categories, the difference between the average milk yield obtained by the least experienced (Beginner) milkman $(20.6 \pm 0.47 \mathrm{~kg})$ and the average milk yield of the most experienced (Advanced) milkman (22.6 \pm 0.59 $\mathrm{kg})$ was found to be statistically significant $(P=0.04)$ (Table 2).

In addition, the difference in milk yields resulting from milking was analyzed economically. The average milk yield difference due to milkman, the income is increased by approximately $3.7 €(0.64 \$)$ per day for a cow (Selling price of $1 \mathrm{~kg}$ of milk $(2.3 €(0.40 \$)) X$ $2.32 \mathrm{~kg})$ and 184 ₹ (31,9 \$) per day for 35 cows (Table 3).

The average milk yield difference due to milkman experience, the income is increased by approximately 3 ₹ $(0.52 \$) /$ day/cow (Selling price of $1 \mathrm{~kg}$ of milk

\section{Discussion and Conclusion}

Human factor is one of the factors affecting animal health and productivity in dairy cows and milkman plays an important role in effective management of animals. In addition, it has been reported that technical training and experience of milkman's on the behavioral characteristics of cow can increase milk yield by applying more effective and stress-free management on animals (de Ondarza, 2019).

In this study, it was determined that the individual and experience characteristics of six different milkmen's had an effect on milk productivity. Similarly, in many studies investigating the effects of herd management and animal welfare on milk yield, it has been stated that milkman experience had a positive effect on milk productivity (Özdemir and Singin 2016; Göncü et al. 2016; Rushen et al. 2001; Akbaş, 2013). However, Munksgaard et al. (2001) reported that milkman experience did not increase the productivity of dairy cow. According to the results of this study, the difference $(2.3 \mathrm{~kg} / \mathrm{day})$ between $1^{\mathrm{st}}$ milkman (highest mean milk yield; $22.6 \pm 0.46 \mathrm{~kg}$ ) and $5^{\text {th }}$ milkman (mean milk yield; $20.3 \pm 0.76 \mathrm{~kg}$ ) was found statistically significant $(P=0.011)$. Due to this difference in the average milk yield, 80 liters of additional milk yield per day and 184 も (31.89\$) additional revenue increase were 
achieved in the farm where 35 cows were milked. This income difference corresponds to the cost of an insured worker. Six milkmen were divided into three categories according to experience level and difference was found to be statistically significant $(P=0.04)$ between the milk yield obtained from the lowest and highest experienced milkman $(20.6 \pm 0.47 \mathrm{~kg}$ $22.6 \pm 0.46 \mathrm{~kg}$ ). This result showed that the income from experienced milkman is about 156 (27.03 \$) more per day. This means that experienced milkman caused $4.4 €(0.76 \$)$ /cow more income per day. As de Ondarza (2019) pointed out, the differences that arise with the experience of the milkman and the milkman can be thought to be due to the fact that the milkman communicates with the animals, acts in a reassuring manner and milking in a stress-free. In addition, experienced milkmen are thought to have more information than lower experienced milkmen about animal behavior, use of milking machines, hygiene and management.

In conclusion, it was determined that the milkman factor was important for the profitability of dairy farming. The experienced milkman may earn its own salary with his provided income increase to the farm and by this way milkman may not cost extra. Therefore, milkmen should be training in terms of animal behavior and hygiene in dairy farms.

\section{References}

Akbaş A. Çiftlik hayvanlarında davranış ve refah ilişkisi. MAKÜ Sağ Bil Enst Derg 2013; 1(1): 42-9.

Alpan O, Arpacık R. Sığır Yetiştiriciliği. 2. Baskı, Ankara: Şahin Matbaası 1998; ss. 184-97.

Bakır G, Kibar M. Muş ilinde bulunan süt sığırcılığı işletmelerinin bazı yapısal özelliklerinin Crostabb analiziyle belirlenmesi KSÜ Tar Doğa Derg 2019; 22(4): 609-19.

Bozkurt Z, Kılıç İ, Hacan ÖG, Lenger ÖF. İnsanhayvan etkileşimlerinin hayvan refahına etkisi. Kocatepe Vet Derg 2013; 6(1): 41-50.

Breuer K, Hemsworth PH, Barnett JL, Matthews LR, Coleman GJ. Behavioural response to humans and the productivity of commercial dairy cows. Appl Anim Behav Sci 2000; 66(4): 273-88.

Çukur F, Saner G. Süt sığırcılığının geliştirilmesinde birliklerin rolü ve önemi: Milas ilçesi süt üreticileri birliği örneği. X. Tarım Ekonomisi Kongresi. September, 5-7, 2012; Konya-Türkiye.

de Ondarza MB, Behaviour. http://www.milkproduc tion.com/Library/Scientific-articles/Animal-welfare/ Behavior/, Accessed Date: 21.08.2019.

Göncü S, Koluman N, Serbester U, Görgülü M. Süt sığırcılığında refah istekleri ve kritik kontrol noktaları. Çukurova Tarım ve Gıda Bil Derg 2016; 31 (1): 9-20.

Hemsworth PH, Coleman GC. Human-livestock interactions-the stockperson and the productivity and welfare of intensively farmed animals. JSAVA 1998; 69: 92-2.

Hemsworth $\mathrm{PH}$. Human-animal interactions in livestock production. Appl Anim Behav Sci 2003; 81 (3): 185-98.

Knight $\mathrm{CH}$, Peaker $\mathrm{M}$, Wilde CJ. Local control of mammary development and function. Rev Rep 1998; 3(2): 104-12.

Koyubenbe N, Konca Y. İzmir ili Ödemiş ilçesi süt sanayiindeki gelişmeler üzerine bir araştırma. Hayvansal Üretim 2006; 47(1): 47-53.

Lensink BJ, Fernandez X, Cozzi G, Florand L, Veissier I. The influence of farmers' behavior on calves' reactions to transport and quality of veal meat. J Anim Sci 2001; 79(3): 642-52.

Munksgaard L, DePassillé AMB, Rushen J, Herskin MS, Kristensen AM. Dairy cows' fear of people: social learning, milk yield and behaviour at milking. Appl Anim Behav Sci 2001; 73(1): 15-26.

Öz H, Bilgen H. Bilgisayar destekli sürü yönetimi. Tarım Araştırma Yayım Eğitim Koordinasyonu (TAYEK) hayvancılık grubu bilgi alişveriş toplantısı bildirileri. Nisan, 24-26, 2002; Menemen/IzmirTürkiye.

Özdemir G, Singin E. Sığırlarda barınak, nakil ve insan-hayvan etkileşimi gibi bazı faktörlerin hayvan refahı üzerine etkileri. Erciyes Üniv Vet Fak Derg 2016; 13(3): 215-22.

Rushen J, DePassille AMB, Munksgaard L. Fear of people by cows and effects on milk yield, behavior, and heart rate at milking. J Dairy Sci 1999; 82(4): 720-7.

Rushen J, Munksgaard L, Marnet PG, DePassillé AMB. Human contact and the effects of acute stress on cows at milking. Appl Anim Behav Sci $2001 ; 73(1): 1-14$

Sreekumar D, Experiment-8 full-hand milking of a dairy cow/buffalo. http://14.139.40.199/bitst ream/123456789/45102/1/Experiment-8.pdf; Accessed Date: 12.10.2019.

Türkiye Cumhuriyeti Merkez Bankası (TCMB). http:// www3.tcmb.gov.tr. Accessed Date:12.11.2019

Türkiye İstatistik Kurumu (TUIK). Hayvancılık İstatistikleri. http://www.tuik.gov.tr/. Accessed Date: 


\subsubsection{9.}

Yavuz F, Akbulut Ö, Keskin A. Türkiye sığırcılık sektöründe ıslah ve destekleme politikalarının etkinliği üzerine bir araştırma. Turk J Vet Anim Sci 2003; 27 : 645-50. 
